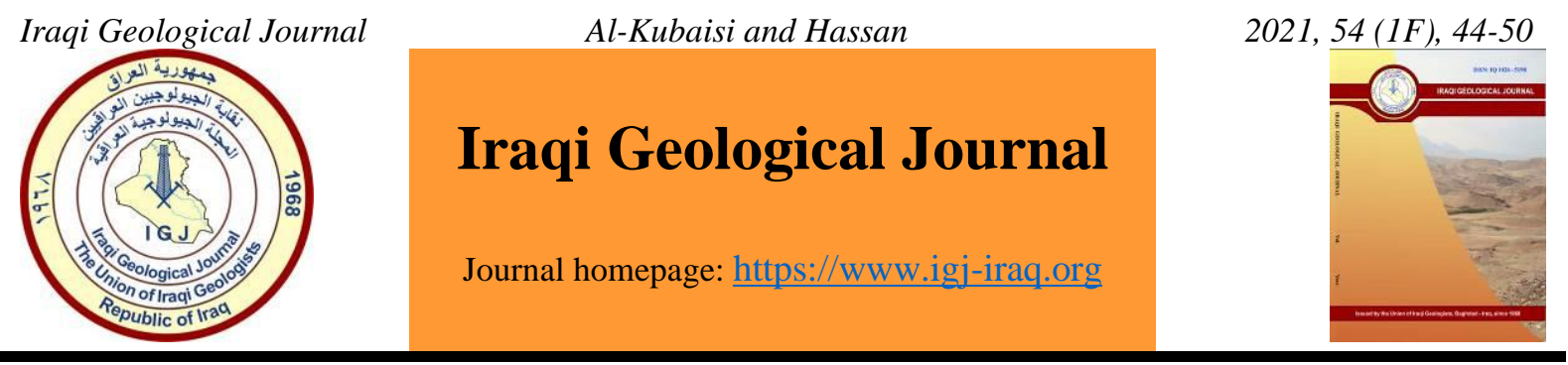

\title{
Isotopic and Hydrochemical Study of Groundwater in an Area Between the Lesser Zab and Tigris River, Northern Iraq
}

\author{
Qusai Y. Al-Kubaisi ${ }^{1}$ and Abdullah S. Hassan ${ }^{1, *}$ \\ 1 Department of Geology, College of Science, University of Baghdad, Iraq \\ * Correspondence: abdallah.salih36@gmail.com
}

Received: 20 February 2021; Accepted: 12 April 2021; Published: 30 June 2021

\begin{abstract}
Stable isotopes $\left({ }^{2} \mathrm{H},{ }^{18} \mathrm{O}\right)$ in the water cycle can carry all the information about the movement of water molecules, their ratio different from one place to another in rainfall. Stable isotopes are the function of evaporation, relative humidity, temperature and different longitude, latitude and altitude. On this base. A total of 28 water sample (20 samples were analyzed for major ions and 8 samples for stable isotopes) were collected for two periods to study the origin and the type of groundwater in the area between Lesser Zab and the Tigris river The Results indicated that groundwater samples in the study area are brackish saline water and excessively mineralized water. The average groundwater was classified as $\mathrm{Mg}-\mathrm{Na}-\mathrm{Calcium}$ : Cl-Sulfate for two periods. The groundwater samples represent earth alkali with privilege sulfate and chloride according to the piper diagram. The mean values of ${ }^{18} \mathrm{H}$ and ${ }^{2} \mathrm{O}$ in the groundwater sample are -27.7 and -4.9 , respectively for the dry period, and -29.8 and -5.2 , respectively, for the wet period. The d-excess varies significantly depending on the humidity and temperature at the vapor source. Isotopic analysis of ${ }^{2} \mathrm{H}-{ }^{18} \mathrm{O}$ for groundwater in the study area shows that the origin of groundwater in the study area is of meteoric origin from global source and rain from a local source. The downward shifting of the regression line on the ${ }^{2} \mathrm{H}-{ }^{18} \mathrm{O}$ diagram indicates that the samples have undergone evaporation events.
\end{abstract}

Keywords: Groundwater, Lesser Zab, Hydrochemistry, Stable isotopes

\section{Introduction}

In the last decades, groundwater starts to play a vital role in arid and semi-arid regions to sustain economic development and to ensure water security for rural communities(Liu et al., 2015). The main reason for the large water demand is human growth population, increasing land used for agriculture and industrial projects as well as the decreased amount of rainfall and water supply in the last years (Awadh and Al-kilabi, 2014). Groundwater is affected by many ecological processes that might cause groundwater disruption. Thus, a sustainable groundwater strategy plan and deep understanding of the geochemical evolution of groundwater is needed in order to guarantee the sustainability of groundwater (Fu et al., 2018). Groundwater characteristics can be utilized in addressing different geochemical problems, where the groundwater contains many soluble minerals derived from several factors such as the interaction between rocks and water (Awadh et al., 2016) and soluble product of rock weathering DOI: $10.46717 /$ igj.54.1F.5ms-2021-06-25 
(Chenini et al., 2010). Hydrochemistry plays a key role to understand groundwater management (Ali et al., 2021). Globally, physio-chemical parameter is of great important to assess the groundwater quality. The physical parameter is represented by total dissolved solids (TDS), hydrogen ions concentration $(\mathrm{pH})$ and electrical conductivity (Ec), whereas the chemical parameters are defined by the major cations $\left(\mathrm{Na}^{+}\right.$, $\mathrm{Mg}^{2+}, \mathrm{Ca}^{2+}, \mathrm{K}^{+}$) and the major anions $\left(\mathrm{Cl}^{-}, \mathrm{SO}_{4}{ }^{2-}, \mathrm{HCO}_{3}{ }^{-}\right.$) (Fetter, 2001). However, it is never enough to determine the origin of water (Tweed et al., 2019). Therefore, isotopes composition has been used commonly in hydrology as a tool to investigate and understand different hydrogeological process such as rainfall, groundwater recharge and surface water-groundwater interactions(Al-paruany et al., 2017). As well as, determine the origin and give answer about the change in the pathway, such as the interaction between the groundwater and surface water, determine groundwater velocity and to determine the residence time of groundwater (Ali et al., 2015). The use of stable isotopes $\left({ }^{18} \mathrm{O}\right.$ and ${ }^{2} \mathrm{H}$ ) has gained a wide acceptance between hydrological professionals, especially when it comes to water investigation (Mazor and Dekker, 1997). The ratio between ${ }^{2} \mathrm{H} /{ }^{1} \mathrm{H}$ and ${ }^{18} \mathrm{O} /{ }^{16} \mathrm{O}$ in stable isotopes is expressed by $\delta^{2} \mathrm{H}$ and $\delta^{18} \mathrm{O}$.where $\delta=\left(\mathrm{R}\right.$ sample/R SMOW - 1) $1000, \mathrm{R}={ }^{2} \mathrm{H} /{ }^{1} \mathrm{H}$ or ${ }^{18} \mathrm{O} /{ }^{16} \mathrm{O}$ the last is taken from SMOW or V-SMOW(Craig, 1961). In Iraq demand for water has increased dramatically due to human growth population and newly established land for agriculture, therefore, the main objective of This study aims to and investigate the groundwater source by using stable isotopes $\left({ }^{2} \mathrm{H}\right.$ and $\left.{ }^{18} \mathrm{O}\right)$, assess the hydrochemistry of groundwater by determining the dominant cations and anions groups, and its suitability for drinking water.

\section{Location and Geological Setting}

The study area located in the north east of Salah Al-Din and west of Kirkuk between Longitude $\left(35^{\circ} 27^{\prime} 00^{\prime \prime}-35^{\circ} 15^{\prime} 00^{\prime \prime} \mathrm{N}\right)$ and latitude $\left(43^{\circ} 14^{\prime} 40^{\prime \prime}-43^{\circ} 36^{\prime} 00^{\prime \prime} \mathrm{E}\right)$ (Fig. 1), it is bounded from the east by the Tigris River and from the west by Lesser Zab river covering an area of about $600 \mathrm{~km}^{2}$ approximately. The climate in this area is arid-semi arid with an average annual temperature, relative humidity, wind speed, rainfall and evaporation of about $22.29{ }^{\circ} \mathrm{C}, 48.1 \%, 1.7 \mathrm{~m} / \mathrm{s}, 15.9 \mathrm{~mm}$ and 213.8 $\mathrm{mm}$, respectively. The study area is located in the Himreen-Makhul Subzone (Jassim and Goff, 2006). The outcropping geologic formations in the study area and surrounding from the oldest to the youngest are Azkand (upper Oligocene), Euphrates (lower Miocene), Fatha (middle Miocene), Injana (Upper Miocene), Mukdadyia (lower Pliocene), Bai Hassan(upper Pliocene), and Quaternary deposits (Pleistocene-Holocene). The latter is almost fully cover the study area (Fig.1). The groundwater flow direction trend in the study area runs from the north east part toward the south east part in the study area following the topography of the area. Therefore, the north east part is representing the recharge zone. while, south eastern part representing discharge zone (Jassim and Guff, 2006).

\section{Materials and Methods}

From different location a total of 28 groundwater samples ( 20 samples were analyzed for major ions and 8 samples for stable isotopes) were collected for two periods, the first was carried out during Oct, 2019 (dry season) and the second was carried out during Mar, 2020 (wet season). Some parameters were measured in site (TDS, $\mathrm{pH}$ and Ec). $50 \mathrm{ml}$ volume glass bottles were used for major ions and 500 $\mathrm{ml}$ volume polyethylene bottles were used for stable isotopes sample collection. All the samples were sealed immediately, labeled and sent to analyzed at the laboratory of the ministry of science and technology. The major ion were measured according to APHA (2012), while stable isotopes $\left({ }^{18} \mathrm{O}\right.$ and ${ }^{2} \mathrm{H}$ ) were measured using liquid stable isotope analyzer (LWSIA) (Nada et al., 2020) Table 1. 


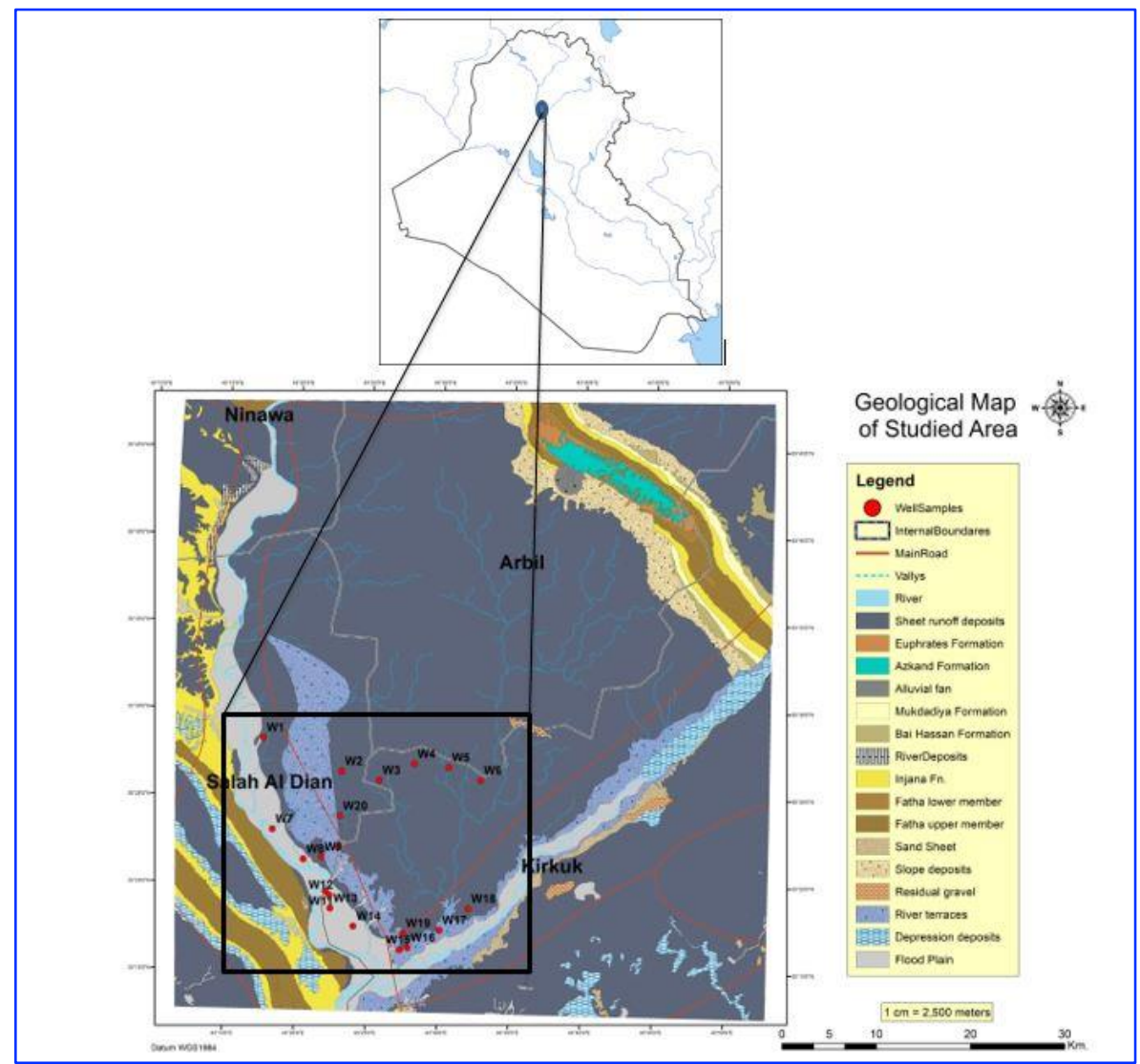

Fig.1. Geological map shows the location of the study area and the location of studied wells

Table 1. Locations of groundwater sampling stations

\begin{tabular}{cccccc}
\hline Well & Easting & Northing & depth(m) & Elevation(m) & S.W.L(m) \\
\hline W1 & 345140 & 3926653 & 9 & 163 & ---- \\
W2 & 353446 & 3923085 & 60 & 193 & 11.5 \\
W3 & 357427 & 3922121 & 14 & 190 & 10.5 \\
W4 & 361158 & 3923851 & 40 & 201 & 15.5 \\
W5 & 364795 & 3923452 & 37 & 193 & ---- \\
W6 & 368200 & 3922077 & 40 & 187 & 9.2 \\
W7 & 346071 & 3916966 & 35 & 156 & 2.6 \\
W8 & 349344 & 3913784 & 10 & 151 & 3.1 \\
W9 & 351275 & 3914017 & ---- & 165 & 12.46 \\
W10 & 353067 & 3914983 & 90 & 175 & ---- \\
W11 & 351678 & 3910375 & 14 & 152 & ---- \\
W12 & 352103 & 3909964 & 9 & 149 & --- \\
W13 & 352195 & 3908553 & 13 & 151 & --- \\
W14 & 354644 & 3906649 & 24 & 142 & 6.2 \\
W15 & 359548 & 3904128 & 41 & 165 & 6.43 \\
W16 & 360409 & 3904355 & 36 & 168 & 12.95 \\
W17 & 363782 & 3906197 & 50 & 158 & 12.83 \\
W18 & 366850 & 3908476 & 40 & 165 & 8.7 \\
W19 & 359904 & 3905880 & 30 & 170 & 6.81 \\
W20 & 353236 & 3918336 & ---- & 180 & 8 \\
\hline
\end{tabular}




\section{Results and Discussion}

\subsection{Hydrochemistry}

The results of the groundwater hydrochemistry are listed in Table 2. The TDS value can be used to reflect the water quality, the last represents a comprehensive hydrochemical parameter (Zhang et al., 2020). TDS values permissible limits in drinking water is $1000 \mathrm{mg} / \mathrm{L}$ (RS2, 2012). The TDS values in the study area range between 1200 and $4650 \mathrm{mg} / \mathrm{L}$ with an average of $2650 \mathrm{mg} / \mathrm{L}$ in the dry period, while it varies from 1132 to 4561 with an average of $2336 \mathrm{mg} / \mathrm{L}$ in the wet period according to (RS2, 2012) the TDS values are exceeding the permissible limits, while groundwater in the study area are classified as brackish-saline water (Altovisky, 1962). The Ec values ranges between 2055 and 8340 with an average of 4262 in the dry period while it ranges between 2030-8290 with an average of 4219 in the wet period, according to Detay (1997) the groundwater samples are excessively mineralized water for two periods. The dominant cations and anion concentration in the groundwater samples follow the order $\left(\mathrm{Ca}^{2+}, \mathrm{Na}^{+}, \mathrm{Mg}^{2+}, \mathrm{K}^{+}\right)$cation $\left(\mathrm{SO}_{4}{ }^{2-}, \mathrm{Cl}^{-}, \mathrm{HCO}_{3}{ }^{-}\right)$anion, the average groundwater type for two periods in the study area are $\mathrm{Mg}-\mathrm{Na}-\mathrm{Calcium}$ : Cl-Sulfate. Piper diagram shows that the groundwater samples in the study area evolved toward the $\mathrm{SO}_{4}$ and $\mathrm{Ca}+\mathrm{Mg}$ pole which represent earth alkali with privileged sulfate and chloride, as shown in Fig. 2.

Table 2. Results of groundwater hydrochemistry for the dry (Oct. 2019) and wet (Mar. 2020) periods

\begin{tabular}{lcccccc}
\hline Variable & \multicolumn{3}{c}{ Dry period } & \multicolumn{3}{c}{ Wet period } \\
\hline $\mathrm{pH}$ & Minimum & Maximum & Average & Minimum & Maximum & Average \\
$\mathrm{TDS}$ & 6.9 & 7.9 & 7.67 & 6.8 & 7.8 & 7.56 \\
$\mathrm{EC}$ & 1200 & 4650 & 2427 & 1132 & 4561 & 2336 \\
$\mathrm{Ca}$ & 2055 & 8340 & 4262 & 2030 & 8290 & 4219 \\
$\mathrm{Mg}$ & 185 & 689 & 370 & 175 & 683 & 353 \\
$\mathrm{Na}$ & 60 & 284 & 114 & 55 & 276 & 109 \\
$\mathrm{~K}$ & 123 & 511 & 281 & 112 & 499 & 269 \\
$\mathrm{HCO}$ & 6 & 10 & 7.7 & 5 & 9 & 6.9 \\
$\mathrm{Cl}_{3}$ & 92 & 464 & 219 & 63 & 425 & 193 \\
$\mathrm{SO}_{4}$ & 230 & 1168 & 581 & 220 & 1170 & 568 \\
\hline
\end{tabular}

\subsection{Isotope Composition of the Groundwater Samples}

Stable isotopes composition of the groundwater samples are shows in Table 3. Isotopes and dexcess values of the groundwater samples at the dry and wet period,s the $\delta$ ranges between -42.2 to 20.14 with an average of -27.7 , and it ranges between (-7.26 and -3.08) with an average of -4.9) for $\delta^{2} \mathrm{H}$ and $\delta^{18} \mathrm{O}$, respectively for the dry period. It ranges between 42.2 and -18.14) with an average of -29.8 , and it ranges between -7.26 and -3.08) with an average of -5.2 for $\delta^{2} \mathrm{H}$ and $\delta^{18} \mathrm{O}$, respectively in comparison the $\delta^{2} \mathrm{H}$ and $\delta^{18} \mathrm{O}$ in the groundwater for two periods, the isotopic composition of $\delta^{2} \mathrm{H}$ and $\delta^{18} \mathrm{O}$ was more enriched in the dry period due to evaporation effect in arid regions (Boschetti et al., 2018). It appears that there is a low variation between the studied periods due to difference in the groundwater conditions (water temperature, water level and climate effect). 


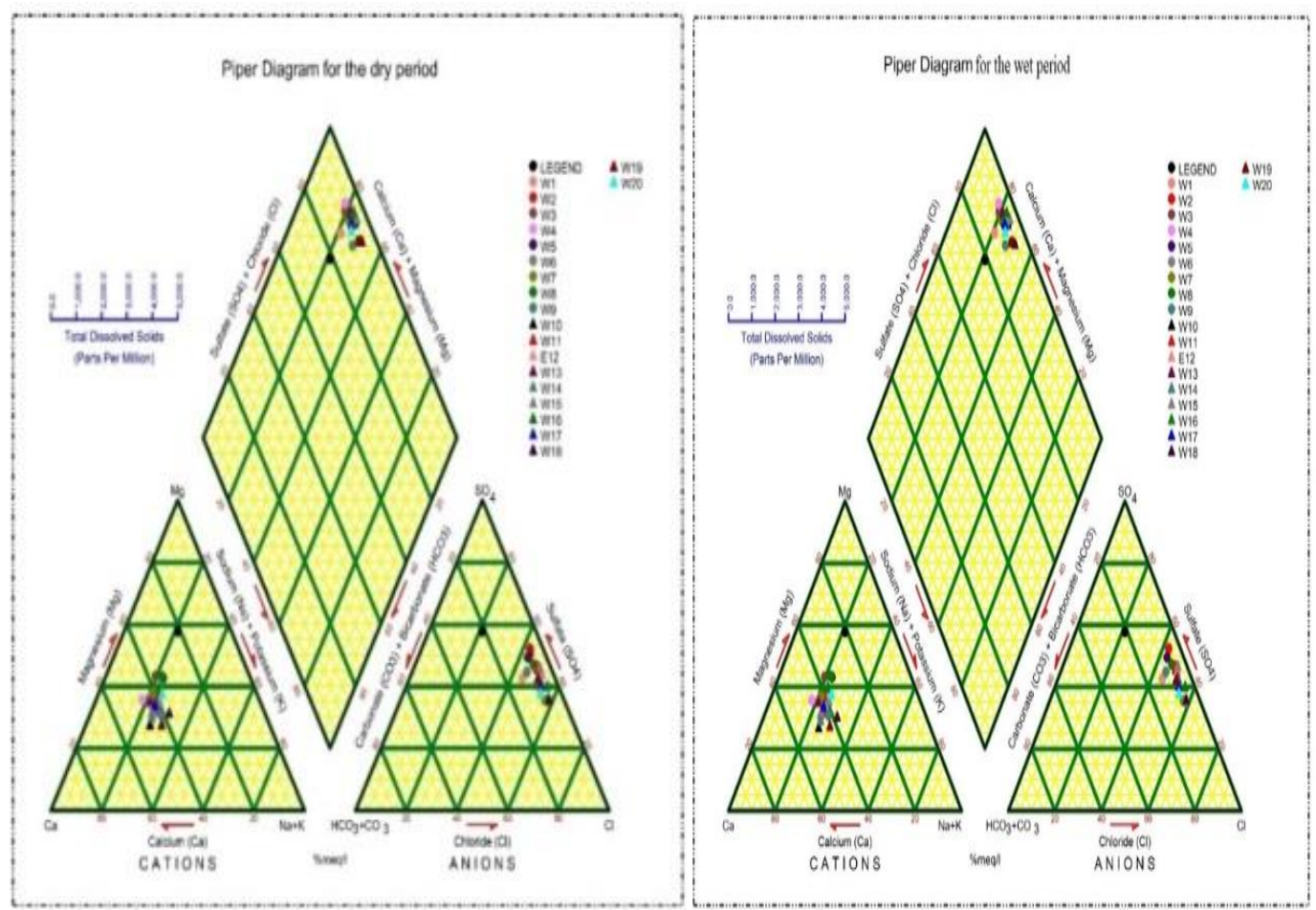

Fig. 2. Piper classification of groundwater samples in the study area for two periods

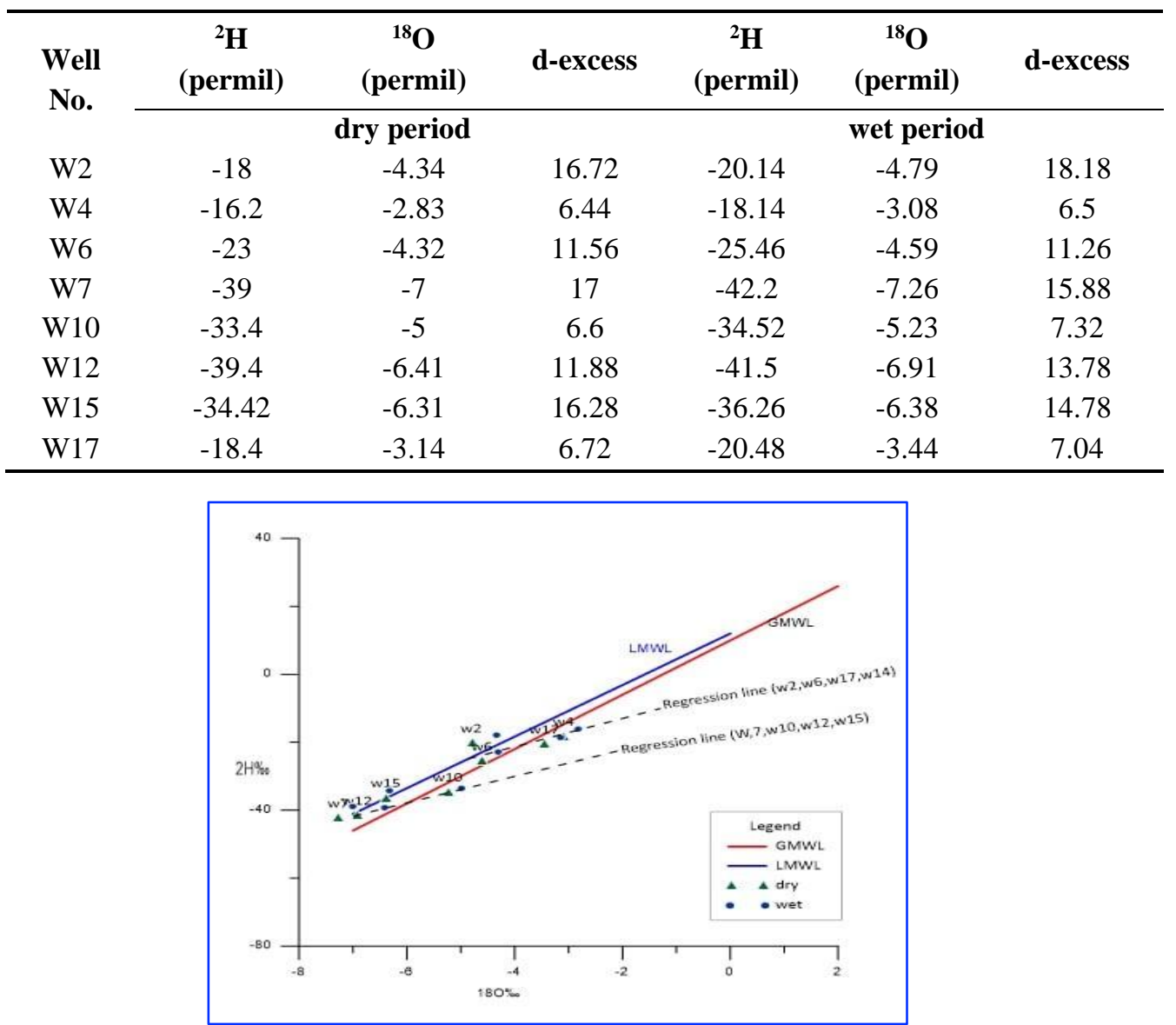

Fig. 3. Isotopes composition of the groundwater in the study area compared with GMWL and LMWL 
Fig. 3 illustrates the relationship between $\delta^{2} \mathrm{H}-\delta^{18} \mathrm{O}$. It shows that most of the isotopes values in the study area lie close to the global meteoric water line (GMWL) (Craig, 1961) and Local meteoric water line (LMWL) (Ali and Ajeena, 2016), this indicate that the groundwater source is of meteoric origin from global source and rain from local source. Moreover, the downward shifting of the regression line indicates evaporation event. That means groundwater effected by evaporation and/or the rain water that recharge the groundwater effected by secondary evaporation (evaporation during event). The deuterium excess is a typical character showing the origin of air. Dansgaard (1946) first proposed the use of the value $(\mathrm{d}=2 \mathrm{H}-818 \mathrm{O})$. to characterize deuterium excess in global precipitation. Deuterium excess was used frequently as a powerful tool to investigate the origin of water vapor, such as humidity and source of water vapor as well as secondary evaporation (evaporation during event) (Zhao et al., 2018). Values of excess ('d') below 10 indicate an evaporation process. Fig. 4 show that most of the dexcess value in the study area (w2, w6, w7, w12 and w15) are higher than the intercept of (GMWL)10\%. this indicate that groundwater is affecting by moisture. Whereas, the rest of sample (w4, w10 and 17) seems to be fall below the intercept of (GMWL) 10\%, which indicate that low-humidity conditions controlling the evaporation at the vapor source region(Zhao et al., 2018).

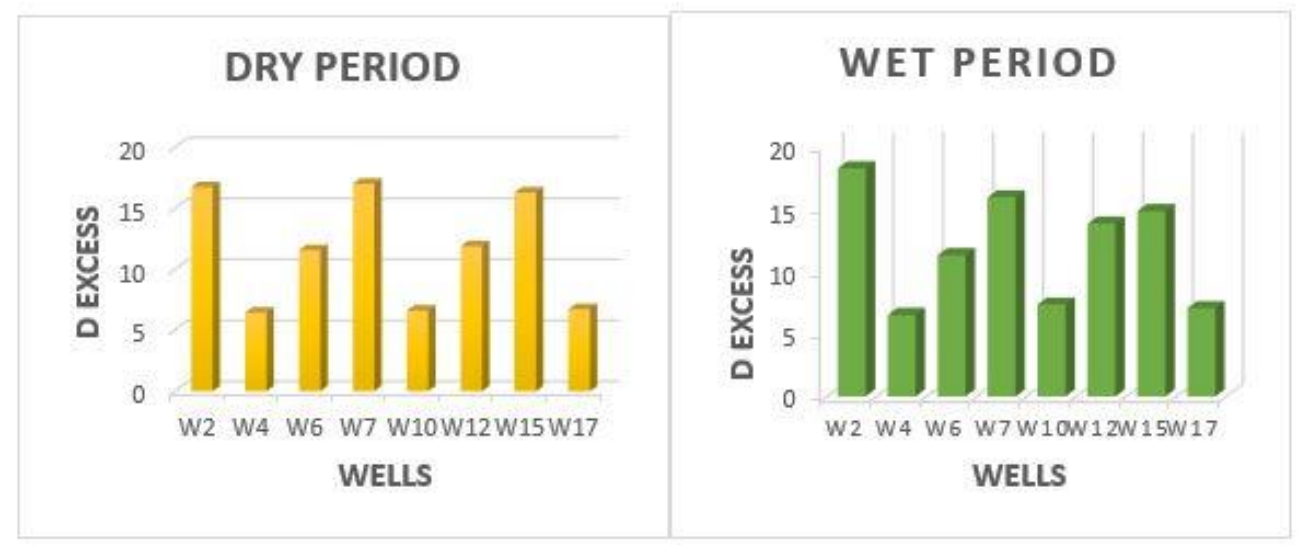

Fig 4. The d-excess values in the groundwater samples in the study area during the dry (Oct. 2019) and wet (Mar. 2020) periods

\section{Conclusions}

The groundwater flow direction trend is from the north eastern part to the south west in the study area following the topography of the area. Concentrations of EC and TDS indicated that the groundwater samples for two periods are brackish saline water excessively mineralized water. The average groundwater type for two periods in the study area are (Mg-Na-Calcium: Cl-Sulfate). Piper diagram shows that the groundwater samples in the study area which represent earth alkali with privilege sulfate and chloride. Isotopic analysis of ${ }^{2} \mathrm{H}-{ }^{18} \mathrm{O}$ for groundwater in the study area shows that the origin of groundwater in the study area is of meteoric origin from global source and rain from local source. groundwater effected by evaporation and/or the rain water that recharge the groundwater and affected by secondary evaporation (evaporation during event).

\section{Acknowledgements}

The authors thank the staff of isotopic laboratory in Ministry of Science and Technology for their support during technical analysis. Our grateful thanks are also extended to Dr. Kamal Al-Paruany for his help in doing the chemical analysis. The authors are very grateful to the Editor in Chief Prof. Dr. Salih M. Awadh, the Secretary of Journal Mr. Samir R. Hijab. and the Technical Editors for their great efforts and valuable comments. 


\section{References}

Al-paruany, K. B. and Al-naseri, S., 2017. Distribution of environmental isotopes in the Euphrates River between Qaim - Falluja, western Iraq, Iraqi Geological Journal, 50(1), 12-27.

Ali, H. A., Al-Shammaa, A. M., Ali K. K., 2021. Hydrochemistry of the Dammam unconfined aquifer southern desert, west Iraq. Iraqi Geological Journal, 54 (1A), 84-98.

Ali, K. K., Ajeena, A. R., 2016. Assessment of interconnection between surface water and groundwater in Sawa Lake area, southern Iraq, using stable isotope technique, Arabian Journal of Geosciences, 9(14).

Ali, K. K., Al-Kubaisi, Q. Y., Al-Paruany, K. B., 2015. Isotopic study of water resources in a semi-arid region, western Iraq. Environmental Earth Sciences, 74(2), 1671-1686.

Altoviski, M. E., 1962. Handbook of Hydrogeology, Gosgoelitzdat, Moscow, USSR, (in Russian), 614 pp.

APHA, American Public Health association, American water works association (AWWA) and Water

environmental Federation (WEF), 2012. Standard methods for the examination of water and wastewater,22nd Edition, 9993 pp.

Awadh, S. M., Abdulhussein, F. M., Al-Kilabi, J. A., 2016. Hydrogeochemical processes and water-rock interaction of groundwater in Al-Dammam Aquifer at Bahr Al-Najaf, Central Iraq, Iraqi Bulletin of Geology and Mining, 12(1), 1-15.

Awadh, S. M., Al-kilabi, J. A. H., 2014. Assessment of groundwater in Al-Hawija (Kirkuk Governorate) for irrigation purposes, 2(55), 760-767.

Boschetti, T., Awadh, S. M., Mariani, E. S., 2018. The Origin and - $\mathrm{MgCl} 2-\mathrm{NaCl}$ Variations in an Athalassic Sag Pond : Insights from chemical and isotopic data. Aquatic Geochemistry, 24, 137-162.

Chenini, I., Farhat, B., Ben Mammou, A. B., 2010. Identification of major sources controlling groundwater chemistry from a multilayered aquifer system. Chemical Speciation and Bioavailability, 22(3),183-189.

Craig, H., 1961. Isotopic Variations in Meteoric Waters. Science, 133(3465),1702-1703.

Detay, M., 1997. Water wells implementation, maintenance and restoration. John Wiley \& Sons, London, 379 pp.

Fu, C., Bai, Z., 2018. A hydrochemistry and multi-isotopic study of groundwater origin and hydrochemical evolution in the middle reaches of the Kuye River basin. Applied Geochemistry, 98, 82-93.

Jassim, S.Z., Goff, J. C., 2006. Geology of Iraq. Pub., Doline, 1st edit, 341pp.

Liu, F., Bu, H., 2015. The role of anthropogenic and natural factors in shaping the geochemical evolution of groundwater in the Subei Lake basin, Ordos energy base, Northwestern China. The Science of the total environment, 538, 327-340.

Mazor, E., Dekker, M.,1997. Chemical and Isotopic Groundwater Hydrology, Environment International, 472 pp.

Nada, K. B., Ajeena, A. R., Al-Kubaisi, Q. Y., Falih, A. H., 2020. Application of stable isotopes to evaluate the interaction between surface water and groundwater in north east of Diyala, Iraq. Iraqi Geological Journal, 53(2F), 108-121.

RS2, 2012. Potable water specification,2nd Ed, Rwanda Bureau of standard, kigali.

Tweed, S., Cartwright, A., Bass, Y., Travi, V., Marc, T., Nguyen, B., 2019. Stable Isotopes of Water in Hydrogeology, Encyclopedia of Water, 1-10.

Zhang, B., Zhao, D., Zhou, P., Qu, S., Lio, F., Wang, G., 2020. Hydrochemical characteristics of groundwater and dominant water - rock interactions in the Delingha. Water, 12(836), 1-16.

Zhao, D., Wang, G., Fu, L., Nuan, Y., Jiang, W., Liang, G., Shi, Z., 2018. Groundwater-surface water interactions derived by hydrochemical and isotopic (222Rn, deuterium, oxygen-18) tracers in the Nomhon area, Qaidam Basin, NW China. Journal of Hydrology, 565, 650-661. 